\title{
From tartrate to taxoids: a double, intramolecular Diels-Alder strategy
}

\author{
Alex G. Fallis \\ Ottawa-Carleton Chemistry Institute, Department of Chemistry, University of Ottawa, \\ 10 Marie Curie, Ottawa, Ontario, Canada, KIN 6N5
}

\begin{abstract}
Various intramolecular [4 +2] cycloaddition strategies directed toward the eventual total synthesis of the potent anti tumor agent paclitaxel (Taxol ${ }^{\circledR}$ ) are outlined. The initial model studies employed a substituted cyclohexene to hold the dienophile and the diene in proximity for the cycloaddition to yield the requisite tricyclo[9.3.1.03,8]pentadecene skeleton. Routes to ring A building blocks and the appropriate dienes have been developed and elaborated into more highly substituted Diels-Alder precursors. Unfortunately, these failed to cyclize and a new strategy has been selected in which a tartrate "tether control group" both directed the initial cycloaddition to a substituted decalin and imparted the required asymmetry. Ring cleavage followed by selective functional group manipulation will afford a new dienedienophile combination from which the desired tricyclic nucleus may be constructed by Lewis acid catalyzed cycloaddition.
\end{abstract}

\section{INTRODUCTION}

The potent anti-tumor agent paclitaxel (Taxol ${ }^{\circledR}$ ) was approved for the treatment of ovarian and breast cancer in 1993. This was more than 20 years after its structure was initially reported (ref. 1), and more than 30 years after its cytotoxicity was first detected. The medicinal potential for the taxoid family is further illustrated by the fact that a semi-synthetic analogue, docetaxel (Taxotere ${ }^{\circledR}$ ) was approved for use in Canada in 1995 (ref. 2). These compounds belong to a new class of anti-tumor drugs that interfere with the normal microtubule-tubulin cascade prior to cell division (ref, $2 b, 3$ ). This novel mode of action, plus the significant synthetic challenge presented by the sterically congested multicyclic structure have stimulated worldwide interest in these molecules (ref. 4). Recently three groups have reported total syntheses of taxol itself (ref. 5). In spite of this success much remains to be investigated and over the next decade it is likely that simpler analogues with a better therapeutic profile will be synthesized and become useful pharmaceutical products. They will thus follow the path from natural products to pharmaceuticals established earlier for penicillins, tetracyclines, etc. A path that depends upon improved knowledge of structure-activity relationships, the development of efficient synthetic and/or semi-synthetic routes to the functionalized tricyclo[9.3.1. $0^{3,8}$ ]pentadecene nucleus, and the development of medicinally interesting analogues that possess a better therapeutic profile than $\operatorname{Taxol}^{\circledR}$ itself.
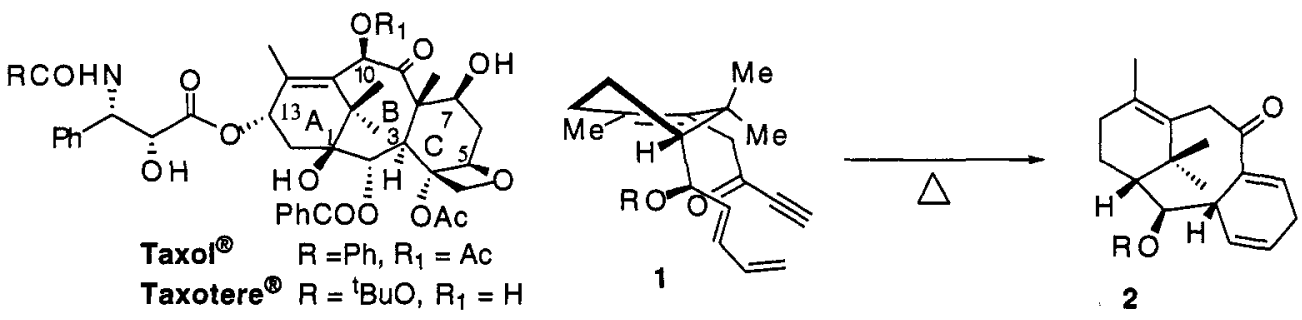

2

\section{INITIAL APPROACH}

We have been developing a strategy that proceeds in the left to right direction (ring A to BC) (ref. 6). Ring A cyclohexene building blocks are used as anchors to facilitate an intramolecular Diels-Alder reaction to construct the $\mathrm{B}$ and $\mathrm{C}$ rings simultaneously. Model studies using this convergent approach led to the 
functionalized tricyclo[9.3.1.03,8]pentadecene skeleton. The $\mathrm{C}_{2}$ epimer controls the adduct stereochemistry in accord with other studies concerning the $\pi$-facial selectivity of related cycloadditions (ref. 7). This is represented by the successful preparation of the adduct 2 from 1 .

Scheme 1. Convergent Inter- Intramolecular Double Diels-Alder Approach

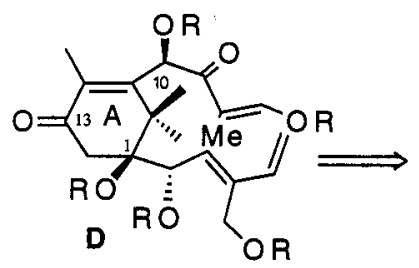<smiles>CC1=C(C)[C@@](C)(C=O)[C@](C)(O)CC1=O</smiles><smiles>[X]C=C(C=C)C=O</smiles><smiles>[X]C(=C)C(C)=C(C(C)C)C1OCC(C)(C)CO1</smiles>

The required ring A building blocks were constructed using $\beta$-ionone $(3)$ as a starting material or alternatively, a Diels-Alder sequence as illustrated (Scheme 1) (ref. 8). Thus, construction of the A ring by an intermolecular cycloaddition ( $\mathbf{X}$ plus $\mathbf{Y}$ ), installation of the $\mathrm{C}_{13}$ oxygen by allylic oxidation and

Scheme 2. Synthesis of Ring A Building Blocks

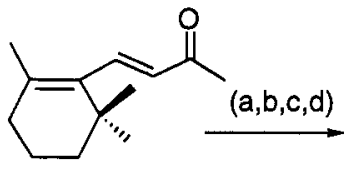

3
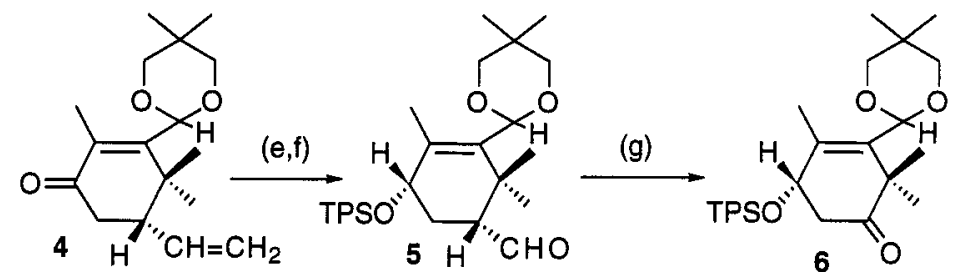

(a) $\mathrm{O}_{3}, \mathrm{CH}_{2} \mathrm{Cl}_{2},-78{ }^{\circ} \mathrm{C}, \mathrm{Me}_{2} \mathrm{~S}$; oxalic acid, $\mathrm{HOCH}_{2} \mathrm{CMe}_{2} \mathrm{CH}_{2} \mathrm{OH}, \mathrm{C}_{6} \mathrm{H}_{6}, 80^{\circ} \mathrm{C}, 64 \%$; (b) $\mathrm{SeO}_{2}, \mathrm{~K}_{2} \mathrm{HPO}_{4}$, toluene, $110^{\circ} \mathrm{C}$; PDC, $\mathrm{MgSO}_{4}, \mathrm{CH}_{2} \mathrm{Cl}_{2}, 62 \%$; (c) LDA, THF, $-78^{\circ} \mathrm{C}, \mathrm{PhSeBr}$; Oxone, ${ }^{\circledR} \mathrm{NaHCO}_{3}, \mathrm{MeOH}, 65 \%$; (d) THF, $\mathrm{CH}_{2}=\mathrm{CHMgBr}$, Cul, TMSCl, $-78^{\circ} \mathrm{C}, 69 \%$; (e) $\mathrm{NaBH}_{4}, \mathrm{MeOH}, \mathrm{CeCl}_{3} .7 \mathrm{H}_{2} \mathrm{O}, 0^{\circ} \mathrm{C}, 96 \%$; TPSCl, DMAP, $\mathrm{CH}_{2} \mathrm{Cl}_{2}$, $21^{\circ} \mathrm{C}, 97 \%$; (f) $\mathrm{O}_{3}, \mathrm{CH}_{2} \mathrm{Cl}_{2},-78{ }^{\circ} \mathrm{C}, \mathrm{Me}_{2} \mathrm{~S}, 96 \%$; (g) TBSOTf, collidine, $\mathrm{CH}_{2} \mathrm{Cl}_{2}, 21^{\circ} \mathrm{C} ; \mathrm{O}_{3}, \mathrm{CH}_{2} \mathrm{Cl}_{2},-78{ }^{\circ} \mathrm{C}$, $\mathrm{Me}_{2} \mathrm{~S}, 17 \%$.

Scheme 3. Halodiene Syntheses
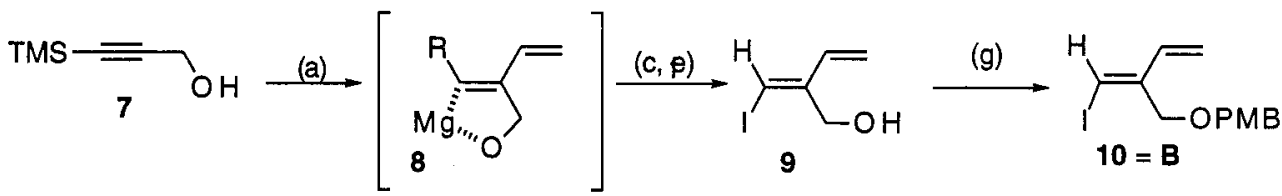

(a) $\mathrm{CH}_{2}=\mathrm{CHMgCl}, \mathrm{THF}, 0-67^{\circ} \mathrm{C}, 16 \mathrm{~h}$;

(b) Aq. $\mathrm{NH}_{4} \mathrm{Cl}, 0^{\circ} \mathrm{C}, 2 \mathrm{~min} .75 \%$;

(c) $\mathrm{l}_{2}$, THF, $-78^{\circ} \mathrm{C}, 1.5 \mathrm{~h}, 53-60 \%$;

(d) TIPSCl, imidazole, $\mathrm{CH}_{2} \mathrm{Cl}_{2}, 0^{\circ} \mathrm{C}, 2.3 \mathrm{~h}$, $88 \%$;; (e) $\mathrm{MeOH}, \mathrm{NaOMe}, 65^{\circ} \mathrm{C}, 45 \mathrm{~min}$.,

(b) TMS<smiles>C=C/C(=C\S)CO</smiles><smiles>C=C/C(=C\Br)CO[Na]</smiles>
$87 \%$; (f) NBS, DMF, $21^{\circ} \mathrm{C}, 1 \mathrm{~h}, 87 \%$; (g) $\mathrm{NaH}$ THF, $0^{\circ} \mathrm{C}$, DMF, $4-\mathrm{MeOBnCl}, 21^{\circ} \mathrm{C}, 18 \mathrm{~h}, 97 \%$.

Scheme 4. Sidechain Elaboration

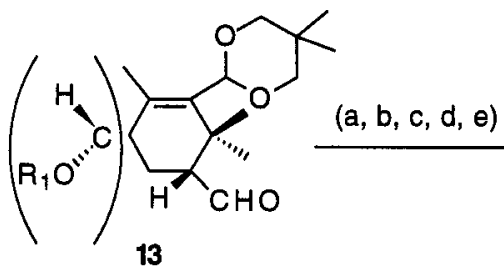<smiles>[R]C(OC)[C@]1(C)CCC(C)=C([C@H](C)O[Sb](C)(=O)=O)C1(C)C</smiles><smiles>CC1CCCCC1C=O</smiles>

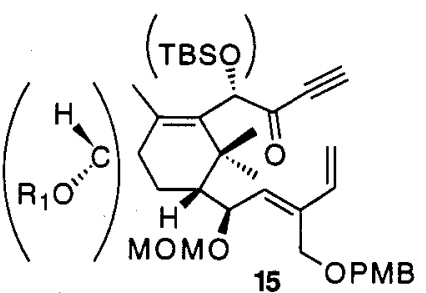

(a) Halodiene = R, ${ }^{\mathrm{s}} \mathrm{BuLi}, \mathrm{THF},-78^{\circ} \mathrm{C}, 90 \%$; (b) $\mathrm{MOMCl},{ }^{\mathrm{i}} \mathrm{Pr}_{2} \mathrm{NEt}, \mathrm{CH}_{2} \mathrm{Cl}_{2}, 21^{\circ} \mathrm{C}, 85 \%$;

(c) THF: $5 \% \mathrm{HCl}, 3: 1,21{ }^{\circ} \mathrm{C}, 99 \%$; (d) TBSCN, $70 \%, 12 \%$; (e) DIBAL, $\mathrm{CH}_{2} \mathrm{Cl}_{2}, 40 \%$;

(f) $\mathrm{HCCMgCl}$, THF, $0^{\circ} \mathrm{C}, 86 \%$; (g) Dess-Martin Ox, $85 \%$. 
utilization of an intramolecular Diels-Alder reaction (D) for the BC rings should afford the desired functionalized nucleus. It was anticipated, that with the $C_{13}$ ketone in place (D) the cyclohexenone would help suppress bond migration, flatten the ring, remove the axial interaction and lead to improved yields.

The ring A aldehydes were prepared (Scheme 2) (ref. 8) and combined with the diene unit $\mathbf{B}$ using both the $E$ and $Z$ isomers independently (ref. 9). The most direct route relied on manipulation of the magnesium salt 8 (Scheme 3) (ref. 10).

Diene addition to the ring $A$ aldehydes (with or without the $C_{13}$ oxygen, 13) proceeded in a diastereoselective manner $(6: 1)$ to provide the new secondary alcohol which was protected as its monomethyl ether derivative (cf., 14, Scheme 4). This set the stage for the installation of the required dienophile by chain extension, reduction, Grignard addition and Dess-Martin oxidation. (Scheme 4, 13 to 15) These procedures were performed with a variety of ring A intermediates and led to a large family of Diels-Alder precursors. Unfortunately, significant effort with a variety of systems, under different conditions (Scheme 5), failed to afford decent yields of the requisite adducts (ref. 11). Thus a new double Diels-Alder strategy has been designed to capitalize on the knowledge gained to date using some of the same building blocks prepared above.

Scheme 5. Summary of Cycloadditions

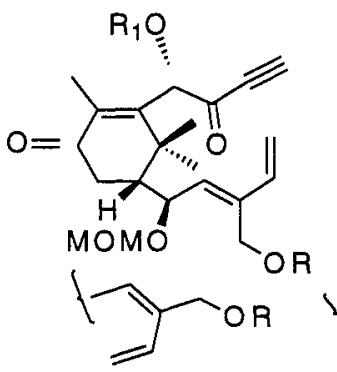<smiles>C=CC(C=O)=CC1(C(C)(C)C)CC1</smiles>

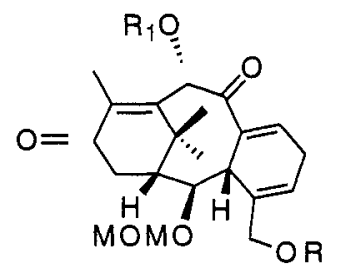<smiles>C=C(C)C(=O)I</smiles><smiles>C=CC(=O)[IH]CCO/C=C(/OCC)C(=O)I</smiles>

$\mathrm{R}=\mathrm{PMB}$ or $\mathrm{Me}$

\section{DOUBLE, INTRAMOLECULAR DIELS-ALDER STRATEGY}

Scheme 6. Aromatic Ring in the Tether<smiles>C=CC(=CC(O)c1cc(C)ccc1C(O)C(=O)O)CO[R16](=O)[O-]</smiles>

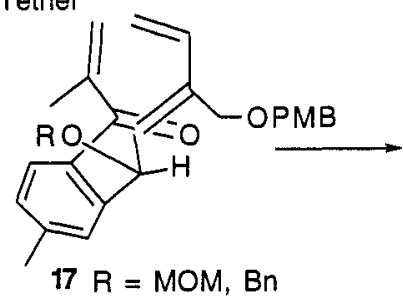<smiles>CCCOCC1=CCC[C@]2(C)C(=O)c3ccc(C)cc3[C@H](O)[C@]12C</smiles>

$1877-83 \%$

Scheme 7. Tartrate Based, Double, Intramolecular Diels-Alder Approach

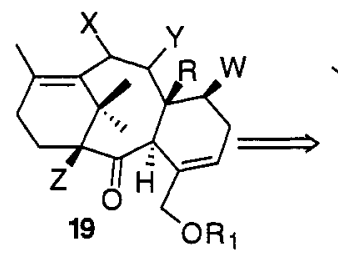

$R=$ COOMe

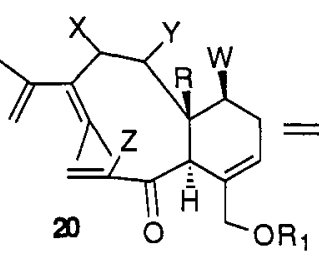

$W, X, Y, Z=$ various oxygens

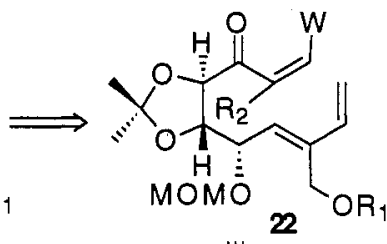

III

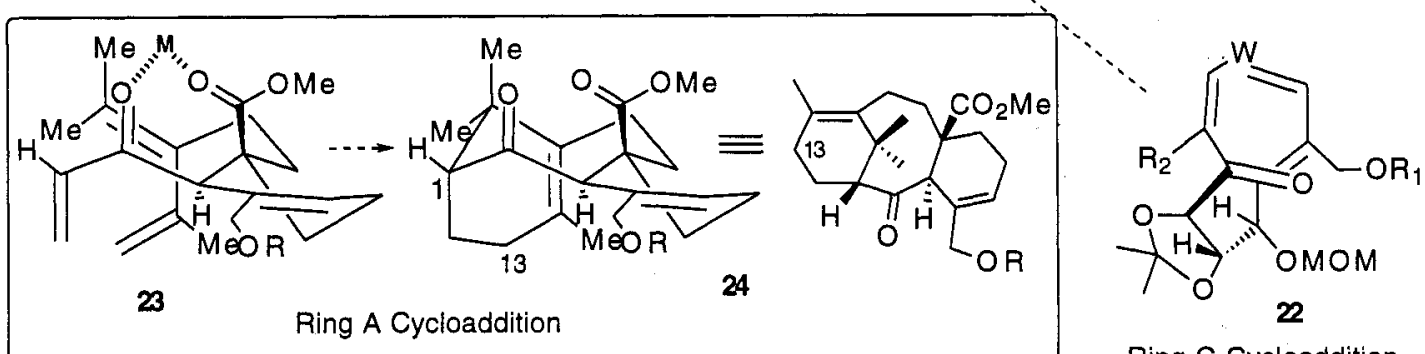

Ring C Cycloaddition

In related research we are developing various "tether control groups" for intramolecular pericyclic, radical, enolate, and metal mediated reactions. These groups impose a restricted geometry on the reactive 
components, facilitate the achievement of the requisite transition state, and when a chiral group is employed impart enantioselectivity to afford chiral non racemic products. These ideas are being applied to this taxane synthesis by using a tartrate derived control group in the tether.

For example direct cycloadditon routes to decalins require long reaction times, high temperatures and the selectivity is often disappointing (ref. 12). In contrast, we find that with a benzene group in the tether the cycloaddition illustrated (16 to 18 , Scheme 6 ) occurs spontaneously at room temperature to give a single diastereomer. (X-ray) This is due to the ease with which the two reactive components can achieve the necessary overlap required in the transition state, from the conformation 17 , imposed by the presence of the planar aromatic ring.

Scheme 8. Initial Cycloaddition and Cleavage Studies

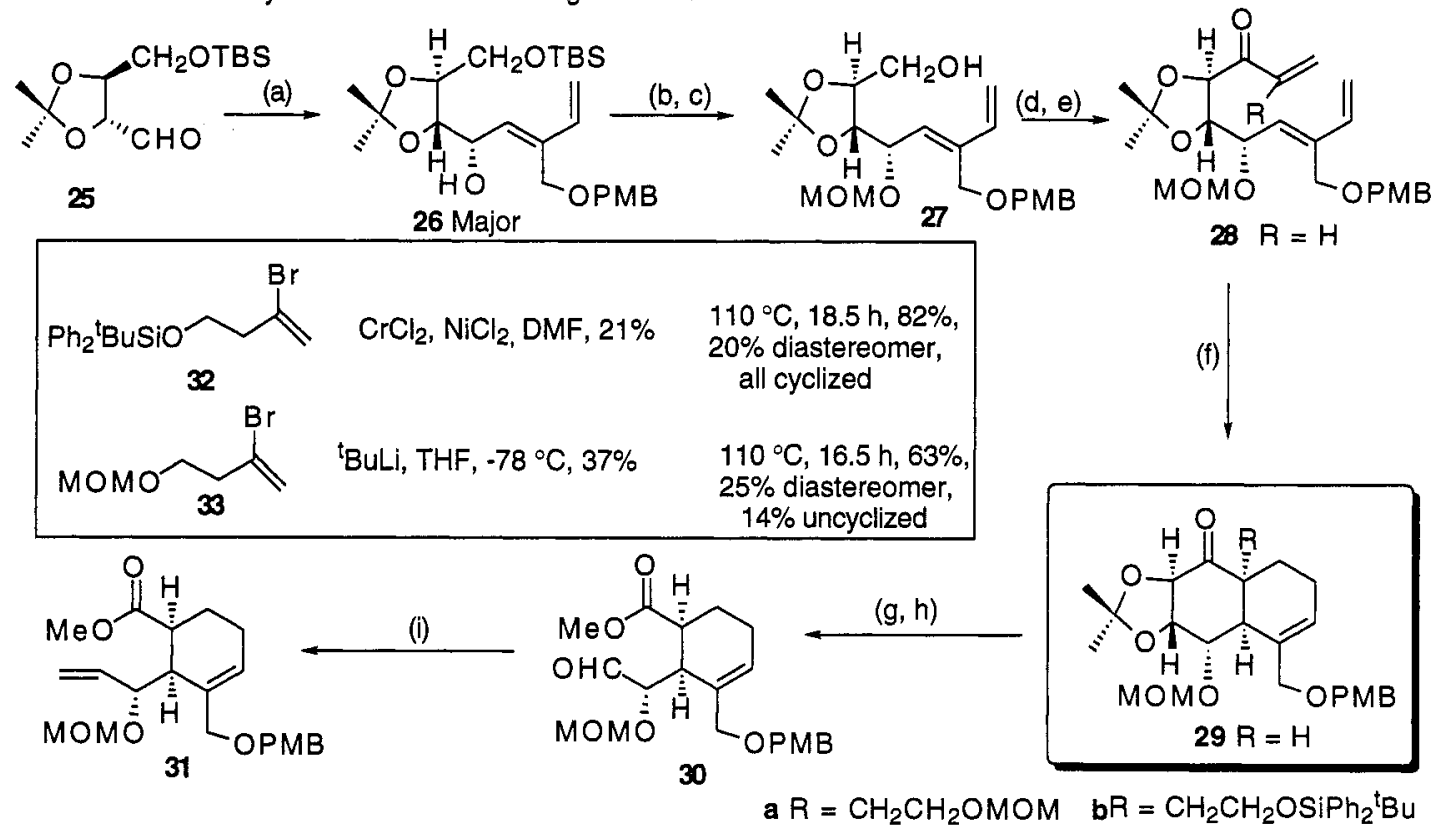

(a) 10, ${ }^{\mathrm{B}} \mathrm{BuLi}, \mathrm{THF},-78^{\circ} \mathrm{C}, 2: 1,89 \%$ or $\mathrm{CrCl}_{2}, \mathrm{NiCl}_{2}, \mathrm{DMF}, 1: 1,70 \%$; (b) MOMCl, ${ }^{\mathrm{P}} \mathrm{Pr}_{2} \mathrm{EtN}, 77 \%$;

(c) ' ${ }^{\mathrm{Bu}}{ }_{4} \mathrm{NF}$, THF, 94\%; (d) Swern Ox, $\mathrm{CH}_{2}=\mathrm{CRBr}$, 'BuLi, THF, $-78{ }^{\circ} \mathrm{C}, 77 \%$; (e) Swern Ox, 63\%;

(f) $\mathrm{C}_{6} \mathrm{H}_{6}, 80^{\circ} \mathrm{C}, 20 \mathrm{~h}, 60 \%$; (g) Aq HCl, THF, 91\%; (h) $\mathrm{Pb}(\mathrm{OAC})_{4}, \mathrm{MeOH}, \mathrm{C}_{6} \mathrm{H}_{6}, 84 \%$; (i) $\mathrm{Ph}_{3} \mathrm{PCH}_{3}{ }^{+}$;

$\mathrm{KN}(\mathrm{TMS})_{2}, \mathrm{C}_{6} \mathrm{H}_{6}, 68 \%$.

Thus use of a tartrate control group should facilitate the enantioselective synthesis of various decalins and related ring systems. In the context of taxoids this leads to an attractive, convergent, sequential Diels-Alder strategy which involves a ring $\mathrm{C}$ cycloaddition to give a decalin (22 to 21 , Scheme 7 ) followed by ring cleavage. Functional group modification of 21 leads to a second Diels-Alder precursor 20. An ester group was selected as a surrogate for the $\mathrm{C}_{19}$ methyl group in order to facilitate the chelated transition state illustrated, in which Lewis acid coordination should occur between this ester and the dienophylic carbonyl (23) to give the adduct 24. Another attractive feature of this approach is the opportunity to attach the A ring in a different fashion using the building blocks above if required.

Scheme 9. Synthesis of Vinyl lodide 40

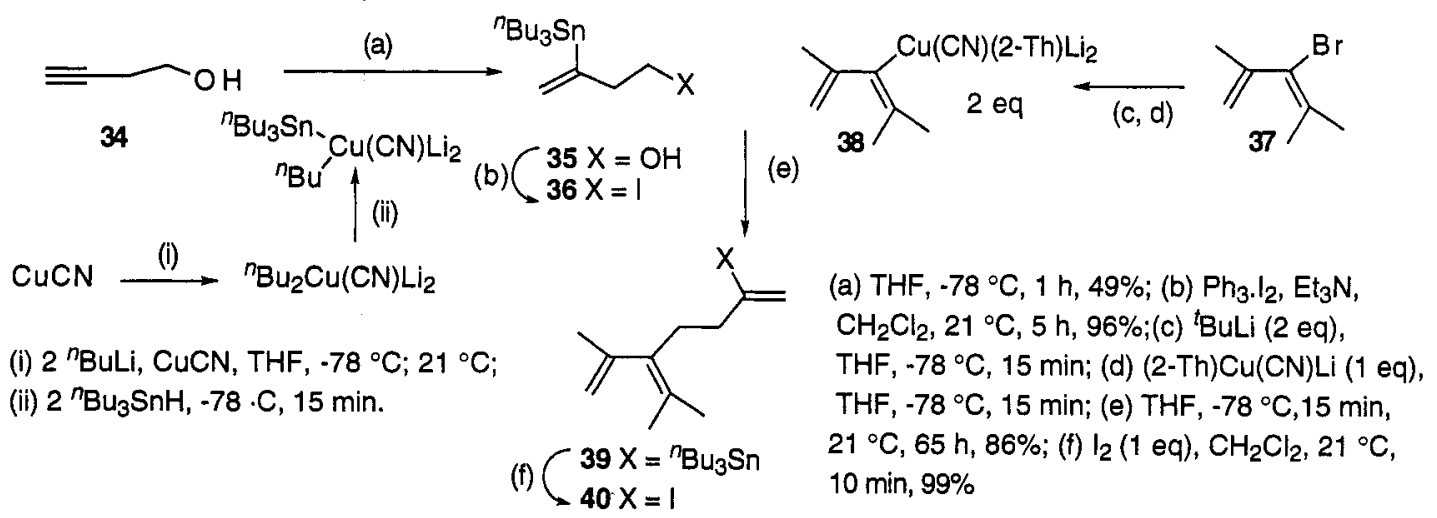


The iododiene 10 was exchanged with $s$-butyllithium and condensed with the silyl ether-aldehyde 25 (Scheme 8) (ref. 13). Unfortunately attempts to improve the diastereoselectivity with a variety of metals have not improved the ratio. However, the major epimer 26 could be separated by chromatography. Addition of the dienophile leads rapidly to the Diels-Alder precursor 28 which cyclized readily to the single enantiomer 29. ( $X$-ray, $R=H$ ), indicative of the control that was anticipated. Ring cleavage to the ester-aldehyde followed by a Wittig condensation provided 31. Attempts to introduce the diene unit in the ester 31 by alkylation were not satisfactory. Thus the vinyl bromides 32 and 33 were prepared from 3butynol (34) and condensed with 25. Cycloaddition of the epimeric mixtures afforded 29a and 29b respectively after chromatography. Unfortunately connection of the diene unit to halo-alkylation agents derived from 29a and 29b also did not proceed cleanly. Consequently a more attractive and convergent alternative is to carry the intact trimethyl substituted diene unit, utilize the ring cleavage to invert the stereochemistry, and set the stage for the final ring A cycloaddition.

Synthesis of the required vinyl anion-trimethyldiene unit proved challenging (Scheme 9) as only the vinyl iodide 40 proved suitable for the $t$-butyllithium exchange reaction. The sequence provides an interesting example of the power of modern cuprate and stannane chemistry for the selective synthesis of vinyl systems.

Scheme 10. Convergent Pentadiene Route

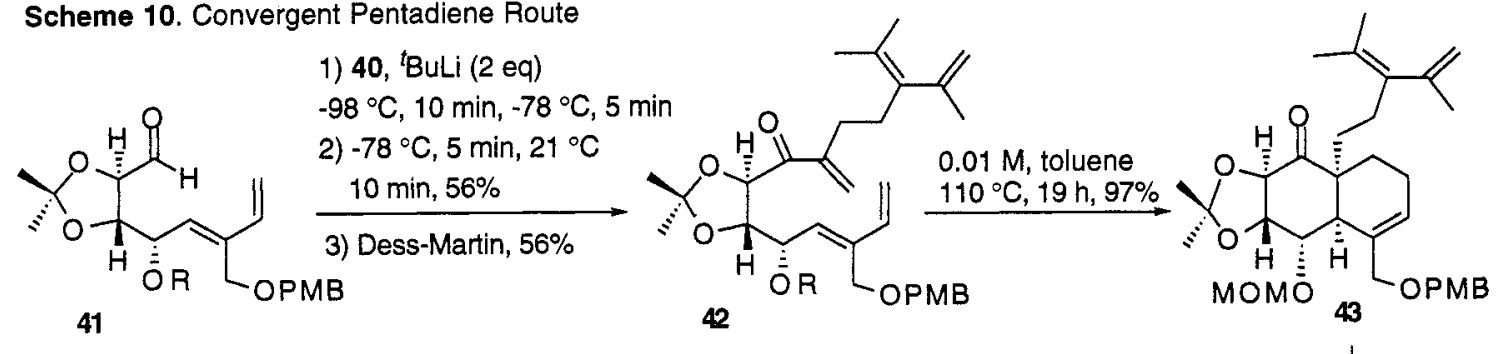

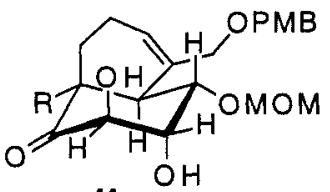

44 $-98^{\circ} \mathrm{C}, 10 \mathrm{~min},-78^{\circ} \mathrm{C}, 5 \mathrm{~min}$ $-78^{\circ} \mathrm{C}, 5 \mathrm{~min}, 21^{\circ} \mathrm{C}$ $10 \mathrm{~min}, 56 \%$ 3) Dess-Martin, $56 \%$ 42 $10 \%$ aq $\mathrm{HCl}-\mathrm{THF}$
$21^{\circ} \mathrm{C}, 1.8 \mathrm{~h}, 72 \%$<smiles>C=C(C)C(CC[C@@]12CCC=C(COC(C)=O)[C@H]1[C@@H](OC)C(OC)OC2=O)=C(C)C</smiles><smiles>C=C(C)C(CC[C@]12CCC=C(COC)[C@H]1[C@@H](OC)[C@H](O)[C@@H](O)C2=O)=C(C)C</smiles>

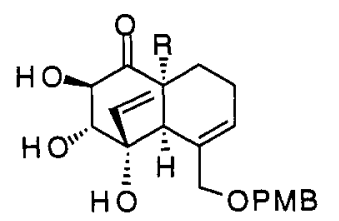
48<smiles>CCI</smiles>

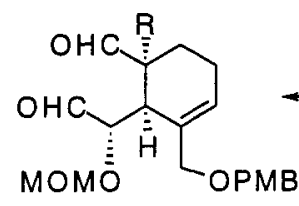
47

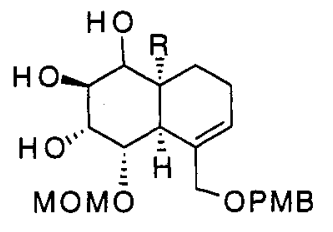

46

Condensation of $\mathbf{4 0}$ with the aldehyde $\mathbf{4 1}$ followed by oxidation afforded the requisite pentadiene $\mathbf{4 2}$ which cyclized smoothly in $97 \%$ yield to the single adduct $\mathbf{4 3}$. As previously, the acetal was cleaved with mild acid to afford the diol $\mathbf{4 4}$ to set the stage for ring cleavage. Unfortunately, in contrast to the example above, this oxidative cleavage with lead tetraacetate was very troublesome. A modest yield of acetallactone $\mathbf{4 5}$ could be obtained and clearly, with the bulky bridgehead substituent now present, the rate of esterification was significantly slower. The diol was inert to treatment with sodium metaperiodate and 
related reagents even at elevated temperatures. This lack of reactivity appears to be a consequence of the preferred conformation of $\mathbf{4 4}$ in which the cyclohexane ring is twisted to minimize the steric interactions between the methoxymethyl ether and the diene substituent. This places the adjacent hydroxyl functions in a diaxial orientation. Thus reagents that require a cyclic intermediate prior to bond cleavage will not be effective. Oxidation to the triketone was not a clean reaction. Thus the ketone was reduced with sodium borohydride to afford the triol 46. Initial cleavage experiments have also been disappointing and treatment with lead tetraacetate did not yield 47 . Consequently, alternative approaches to improve the ring cleavage reaction are also being examined. These include the use of a 'cis-tartrate' precursor for the cycloaddition and examination of the triol 48 . The adduct $48(R=H)$ has been prepared and its oxidative cleavage will be investigated to provide the dienophile component directly.

\section{CONCLUSION}

In summary, a synthetic strategy for taxoids based on a sequential intramolecular Diels-Alder approach appears to hold considerable promise. The principle of using a tartrate 'tether control group' has been shown to be particularly advantageous for directing the initial intramolecular cycloaddition and this concept is currently being extended to other intramolecular reactions. It is anticipated that satisfactory cleavage of 44, 46, 48, or a close relative, will lead, in 12-14 steps, from 25 to the adduct 50 . For the future an $\alpha$-hydroxy ketone substituted version of iodotriene $\mathbf{4 0}$ and the use of an enol ether dienophile are expected to introduce the requisite oxygen functionality at $C_{1}, C_{9}$, and $C_{10}$.

Acknowledgments I wish to thank a very dedicated group of collaborators for their intellectual and experimental contributions to this research. These studies were initiated by I.A. Kennedy, F.-Y. Lu, M.W. Tjepekema, M.A. Romero, H. Audrain, and are being advanced further by T. Wong, P.D. Wilson, J. Axon, and S. Woo. We are grateful to the Natural Sciences and Engineering Research Council of Canada (NSERC), Rhône-Poulenc Rorer, and the Breast Cancer Research Initiative of the Canadian Cancer Institute for financial support of this research.

\section{REFERENCES}

1. M. C. Wani, H. L. Taylor, M. E. Wall, P. Coggan and A. T. McPhail.J. Am. Chem. Soc. 93, 2325 (1971).

2. (a) F. Lavelle, F. Guéritte-Voegelein and D. Guénard. Bull. Cancer 80, 326 (1993); (b) Taxane Anticancer Agents (G. I. Georg, T. T. Chen, I. Ojima and D. M. Vyas. Amer. Chem. Soc. Washington (1994).

3. M. L. Rothenberg. Curr. Opin. Invest. Drugs 2, 1269 (1993).

4. (a) A. N. Boa, P. R. Jenkins and N. J. Lawrence.Contemp. Org. Syn. 47, 47 (1994). (b) K. C. Nicolaou, W.-M. Dai and R.K. Guy. Angew. Chem., Int. Ed. Engl. 33, 15 (1994). (c) D. G. I. Kingston, A. A. Molinero and J. M. Rimoldi. Prog. Chem. Org. Nat. Prod. 61, 1 (1993). (d) C. S. Swindell. Org. Prep. Proced. Int. 23, 465 (1991).

5. (a) R. A. Holton, et al. J. Am. Chem. Soc. 116, 1597 (1994). (b) Ibid. J. Am. Chem. Soc. 116, 1599 (1994). (c) K. C. Nicolaou et al. Nature 367,630 (1994). (d) Ibid. J. Am. Chem. Soc. 117, 624 (1995). (e) Ibid. J. Am. Chem. Soc. 117, 634 (1995). (f) Ibid. J. Am. Chem. Soc. 117, 645 (1995). (g) Ibid. J. Am. Chem. Soc. 117, 653 (1995). (h) J. J. Masters, J. T. Link, L. B. Snyder, W. B. Young and S. J. Danishefsky. Angew. Chem., Int. Ed. Engl. 34, 1723 (1995).

6. (a) Y.-F. Lu and A. G. Fallis. Tetrahedron Lett.34, 3367 (1993). (b) Ibid., Can. J. Chem. 73, 2239 (1995).

7. A. G. Fallis and Y.-F. Lu, $\pi$-Facial Diastereoselection in Diels-Alder Cycloadditions and Related Reactions; in Adv. in Cycloadditions (D. P. Curran, ed.) Vol. 3, pp 1-66. JAI Press: Greenwich, Conn. (1993).

8. M. W. Tjepkema, P. D. Wilson, T. Wong, M. A. Romero, H. Audrain and A. G. Fallis. Tetrahedron Lett. 36, 6039 (1995).

9. T. Wong, M. A. Romero and A. G. Fallis. J. Org. Chem. 59, 5527 (1994).

10. T. Wong, M. W. Tjepkema, H. Audrain, P. D. Wilson and A. G. Fallis. Tetrahedron Lett. 37, 755 (1996).

11. For a succesful, related case see: J. D. Winkler, S. K. Bhattacharya, F. Liotta, R. A. Batey, H. S. Kim, M. Saraiva, S. V. Chandramouli and R. C. Kelly. 211 th American Chemical Society National Meeting, 1996, March 24-28, New Orleans, Abstract ORGN 47.

12. A. G. Fallis, Can. J. Chem.. 62, 183 (1984).

13. H. lida, N. Yamazaki and C. Kibayashi. J. Org. Chem.. 52, 3337 (1987). 